\title{
Effect of frame size on performance and carcass traits of Santa Inês lambs finished in a feedlot ${ }^{1}$
}

\author{
Edmilson Lúcio de Souza Júnior², Wandrick Hauss de Sousa ${ }^{3}$, Edgard Cavalcanti Pimenta \\ Filho $^{4}$, Severino Gonzaga Neto ${ }^{4}$, Felipe Queiroga Cartaxo ${ }^{3}$, Marcílio Fontes Cezar ${ }^{2}$, Maria das \\ Graças Gomes Cunha ${ }^{3}$, José Morais Pereira Filho²
}

\author{
${ }^{1}$ Reserch financed by FINEP/EMEPA/FAPESQ. \\ 2 Unidade Acadêmica de Medicina Veterinária/CSTR/UFCG - Patos - PB, Brazil. \\ ${ }^{3}$ Emepa - PB, Brazil. \\ ${ }^{4}$ Departamento de Zootecnia/CCA/UFPB - Areia - PB, Brazil.
}

\begin{abstract}
The objective of this study was to evaluate the performance, qualitative, morphometric and quantitative carcass traits of Santa Inês lambs of different frame sizes finished in a feedlot. Twenty 120-day-old intact lambs with a $25.0 \pm 3.1 \mathrm{~kg}$ average body weight at the beginning of the experiment were used. Lambs received a diet containing $17 \%$ crude protein and $2.70 \mathrm{Mcal} / \mathrm{kg}$ dry matter. Frame size influenced performance and tissue composition in the carcasses of the lambs. Lambs with large frame sizes showed better carcass conformation compared with those of medium-sized frames. Frame size was found to have a significant effect on rump perimeter. Large-framed lambs showed higher compactness on the carcass index and carcass dressing area compared with medium-framed lambs. The cuts of large-framed lambs weighed more than those of mediumframed lambs. However, no significant differences were found in dressing.
\end{abstract}

Key Words: carcass conformation, commercial cuts, dry matter intake, sheep, tissue composition, weight gain

\section{Introduction}

Sheep farming is expanding in Brazil with the increased production of these animals in various regions. There is a growing demand for sheep meat, and with this comes a search for more suitable farming systems, diets and genotypes.

Finishing lambs in a feedlot has proven to be a valuable alternative that can increase production and improve the quality of the sheep carcass and meat that has been recommended by various authors (Reis et al., 2001; Ortiz et al., 2005). According to Tatum et al. (1986), the intrinsic value of a lamb in a feedlot is a function of its genetic potential.

According to Alves et al. (2003), to improve production and productivity, knowledge of the genetic potential for meat production of an animal is essential. The authors also affirm that among the peculiarities of sheep are their efficient weight gain and high meat quality.

Santa Inês lambs stand out among those finished in feedlots in north-eastern Brazil. Because of years including genotypes from large-framed lambs, such as Suffolks, Santa Inês lambs have both medium and large frame sizes. Therefore, the same breed may include individuals of different biotypes that perform differently and have different carcass traits. Thus, it is necessary to assess these traits in sheep of different frame sizes, particularly the most common sheep race in the north-eastern region of Brazil, Santa Inês. It is important to stress that this assessment is being performed empirically.

According to Tatum et al. (1998), frame size, which is defined by body measurements, is a trait that may influence the rate of growth and the production of meat.

Therefore, the objective of this study was to evaluate the performance, qualitative, morphometric and quantitative carcass traits of Santa Inês lambs of different frame sizes finished in a feedlot.

\section{Material and Methods}

The experimental study was conducted at Estação Experimental Pendência, which belongs to Empresa de Pesquisa Agropecuária da Paraíba S.A. - EMEPA-PB, located in the city of Soledade, in the Meso-region of Paraíba, Brazil.

Initially, 30 intact 120-day-old lambs with a $25.0 \pm 3.1 \mathrm{~kg}$ average body weight were selected, based on a visual appraisal and body measurements.

After biometric measurements, 19 lambs were selected and divided into two groups (medium group, with 9 animals 
and large group, with 10 animals). The classification of the individuals into the two frame sizes was based on the variable frame size index.

The variable frame size index (FSI) was created to categorize animals as to their frame sizes. To calculate this, body measurements front height $(\mathrm{FH})$, back height $(\mathrm{BH})$, body length (BL) and live weight (LW) for each animal were applied to the following calculation:

$$
F S I=\frac{F H+B H+B L+L W}{4}
$$

Animals with FSI from 50 to 57.5 were classified as medium frame size, and animals with FSI from 57.6 to 62 were classified as large frame size.

After health care management (i.e., administration of vermifuge and vaccines), the animals were distributed into individual pens with slatted and suspended floor measuring $0.80 \times 1.20 \mathrm{~m}$, provided with to feeders and drinkers, arranged in two rows in a brick shed.

The experimental period of 40 days was established and the period of adaptation to the diets was 14 days, totaling 54 days. The weight was measured every 14 days, and feed was offered twice a day: in the morning, at $8 \mathrm{~h} 00$ and in the afternoon, at $16 \mathrm{~h} 00$. The dry matter intake per animal was $5 \%$ of the live weight, and the amount of feed offered ensured $10 \%$ orts at the end of each meal, stimulating voluntary intake. Subsequently, calculations of the dry matter intake (DMI) were made. After the 40-day experimental period, the animals were weighed for calculation of their average daily weight gain (ADWG) and feed conversion (CA) and were then slaughtered.

Biometric measurements were obtained at the beginning and end of the experiment (Table 1). The evaluations were performed with the aid of a measuring instrument graduated in centimeters and millimeters. The following measurements were obtained: front height measured from the withers to the ground; back height measured from the top of the croup to the ground; and body length - measured from the point of the shoulder to the rump.

Table 1 - Biometric measurements of the lambs at the beginning and end of the experiment according to frame size

\begin{tabular}{lcccc}
\hline \multirow{2}{*}{ Variables } & \multicolumn{4}{c}{ Frame size } \\
\cline { 2 - 5 } & \multicolumn{2}{c}{ Medium } & \multicolumn{2}{c}{ Large } \\
\cline { 2 - 5 } & Beginning & End & Beginning & End \\
\hline Front height $(\mathrm{cm})$ & $58.5 \pm 3.90$ & $62.1 \pm 3.21$ & $60.2 \pm 1.81$ & $66.0 \pm 2.49$ \\
Back height $(\mathrm{cm})$ & $57.8 \pm 5.28$ & $62.2 \pm 3.07$ & $61.3 \pm 2.30$ & $65.9 \pm 2.23$ \\
Body length $(\mathrm{cm})$ & $55.1 \pm 3.28$ & $62.2 \pm 1.71$ & $56.3 \pm 2.21$ & $65.1 \pm 1.72$ \\
Live weight $(\mathrm{kg})$ & $24.5 \pm 3.08$ & $35.0 \pm 3.69$ & $27.2 \pm 2.89$ & $39.5 \pm 4.04$ \\
\hline
\end{tabular}

A full ration (Table 2) was offered, with a roughage: concentrate ratio of $30: 70$, containing $17.0 \%$ crude protein and $2.70 \mathrm{Mcal} / \mathrm{kg} \mathrm{DM}$.

Slaughter was performed after an 18-hour period of solid food deprivation and a 12-hour period of liquid deprivation, with further suspension of the animals and an eventual concussion stunning, followed by incisions cutting the jugular veins and carotid arteries to release the blood. The animals were slaughtered at Pendência Station, which has a slaughterhouse and cold storage room for cooling the carcasses.

After bleeding and skinning, the gastrointestinal contents and skin, head, feet and genitals were removed. Then, the hot carcass weight (HCW) was obtained and the carcasses were wrapped in plastic bags and transported to a cold room $\left(4^{\circ} \mathrm{C}\right)$ where they remained for 24 hours. The empty body weight (EBW) was calculated by the difference between the final body weight $(\mathrm{FW})$ and the weight of the gastrointestinal contents.

The carcasses were taken to a refrigerated room where they remained hung by the legs for the qualitative evaluation. For the qualitative evaluation of the carcass, conformation and fat were evaluated according to the methodology described by Colomer-Rocher et al. (1988). Based on the methodology proposed by Osório \& Osório (2003), the marbling, color and texture of the longissimus dorsi muscle were evaluated.

After the cooling period, the carcasses were weighed to obtain the cold carcass weight ( $\mathrm{CCW}$ ). The amount of carcass loss by cooling shrinkage was calculated using the formula $(\mathrm{CLC} \%)=\mathrm{HCW}-\mathrm{CCW} / \mathrm{HCW} \times 100$. Afterwards, the carcass was halved longitudinally with a chainsaw (G. Paniz, model SF 42). In the left half of the carcass, a cross-section was made between the 12th and 13th ribs, exposing the longissimus dorsi muscle. Using a transparent

Table 2 - Ingredient and chemical composition of the diet

\begin{tabular}{lc}
\hline Ingredient composition & $(\mathrm{g} / \mathrm{kg})$ \\
\hline Ground corn & 300.0 \\
Tifton hay & 450.0 \\
Soybean meal & 200.0 \\
Wheat bran & 30.0 \\
Salt & 5.0 \\
Mineral salt & 5.0 \\
Limestone & 10.0 \\
Chemical composition & \\
Dry matter roughage/concentrate & 885.1 \\
Crude protein & 170.0 \\
Metabolizable energy (Mcal/kg DM) & 2.70 \\
Neutral detergent fiber & 334.17 \\
Ether extract & 27.6 \\
Mineral matter & 5.14 \\
DM - dry matter. &
\end{tabular}


plastic film, the loin eye area (LEA) was determined using a measuring device (A) and the maximum depth (B) was obtained according to the formula: $\mathrm{LEA}=(\mathrm{A} / 2 * \mathrm{~B} / 2) \Pi$. Fat thickness was measured with a caliper.

The leg muscularity index (LMI) in the lambs was estimated by dissecting the leg tissues. After being weighed, the legs were put into a plastic bag and kept in a freezer at $-20{ }^{\circ} \mathrm{C}$. Legs were later thawed, and the muscle, bone and fat tissues were separated. Then, the femur length was measured to calculate the leg muscularity index in accordance with the methodology described by Purchas et al. (1991).

$$
L M I=\frac{\sqrt{W 5 M \mid F L}}{F L}
$$

where $\mathrm{LMI}=$ leg muscularity index; W5M = weight of five muscles (biceps femoris, quadriceps femoris, semimembranosus, semitendinosus and adductor); and $\mathrm{FL}=$ femur length.

The tissue composition of the carcass was estimated indirectly. Instead of separating the bones, muscles and fat in the whole carcass, the results from the analysis of the tissues in the leg were used - a parameter that has a high correlation with the results obtained from the dissection of the carcass. The percentage of other tissues that comprise the leg was not analyzed.

The internal length of carcass was measured on the right half of the carcass using a measuring tape. This measurement was used to divide the cold carcass weight (CCW) and determine the carcass compactness index (CCI).

Afterwards, the half-carcass was sectioned in the following five commercial cuts: neck - separated from the carcass between the last cervical vertebra and the first thoracic vertebra; shoulder - obtained through a section of the axillary region by cutting the tissues that attach the scapula and humerus to the thoracic region of the carcass; ribs - removed with two cuts: the first was made between the last cervical vertebra and the first thoracic vertebra, and the second was made between the last thoracic vertebra and the first lumbar vertebra; loin - obtained by two cuts: one between the last thoracic vertebra and the first lumbar vertebra and another between the last lumbar vertebra and the first sacral vertebra; and legs - separated from the carcass at the upper end, between the last lumbar vertebra and the first sacral vertebra. As the cuts were removed from the carcass, they were immediately weighed.

The data on the studied variables were subjected to an analysis of variance, following a completely randomized design, using the $\mathrm{F}$ test to compare the mean squares of the factors tested. Means were compared by using Tukey's test $(\alpha=0.05)$. To analyze the performance of results, the effect of the initial weight was added to the model as a covariate. To analyze the results of the carcass traits, the effect of the final live weight was added to the model as a covariate.

The statistical model was as follows:

$$
\mathrm{Yij}=\mu+\mathrm{fi}+\mathrm{eij}
$$

where Yij = observed value of each dependent variable; $\mu=$ overall mean; $\mathrm{fi}=$ effect of frame; and eij $=$ random error associated with each observation.

\section{Results and Discussion}

There was a significant difference between mediumand large-framed lambs in their final weights. Large lambs showed higher values than medium-sized lambs (Table 3).

The frame size of the lamb did not have a significant effect on dry matter intake (kg/day). Large-framed lambs showed an intake of $1.28 \mathrm{~kg} /$ day, and medium-framed lambs had an intake of $1.16 \mathrm{~kg} /$ day, demonstrating that the lambs ate similar amounts of feed daily, regardless of their frame size. For this range of live weights, the NRC (1985) established an intake of 1.0 to $1.3 \mathrm{~kg} /$ day. The lambs consumed amounts very close to this range. The dry matter concentrate ratio most likely led to this high intake. Similar results with $1.2 \mathrm{~kg}$ /day were found by Neiva et al. (2004), who used the same genotype and the same dry matter concentrate ratio used in this study.

Regarding dry matter intake in units of metabolic size, there was no significant difference between the frame sizes. The large-framed lambs ingested $45.64 \mathrm{~g} / \mathrm{kg}^{0.75}$, and the medium-framed lambs consumed $45.49 \mathrm{~g} / \mathrm{kg}^{0.75}$. This method is the most accurate at illustrating dry matter intake because the metabolic weight homogenizes the animals per surface area, eliminating the effect of live weight gain. Therefore, it can be affirmed that the frame size of Santa Inês lambs does not affect the dry matter intake of these animals.

Table 3 - Weights, dry matter intake (DMI), average daily weight gain (ADWG) and feed conversion ratio (FCR) in relation to frame size

\begin{tabular}{lcccc}
\hline \multirow{2}{*}{ Variable } & \multicolumn{4}{c}{ Frame size } \\
\cline { 2 - 5 } & Medium & Large & CV (\%) & P-value \\
\hline Initial weight $(\mathrm{kg})$ & $24.50 \mathrm{a}$ & $27.15 \mathrm{a}$ & 11.52 & 0.070 \\
Final weight $(\mathrm{kg})$ & $35.03 \mathrm{~b}$ & $39.50 \mathrm{a}$ & 10.39 & 0.022 \\
Dry matter intake $(\mathrm{kg} / \mathrm{day})$ & $1.16 \mathrm{a}$ & $1.28 \mathrm{a}$ & 13.92 & 0.170 \\
Dry matter intake $\left(\mathrm{g} / \mathrm{kg}^{0.75}\right)$ & $45.49 \mathrm{a}$ & $45.64 \mathrm{a}$ & 11.61 & 0.951 \\
Dry matter intake $(\% \mathrm{LW})$ & $3.33 \mathrm{a}$ & $3.24 \mathrm{a}$ & 11.85 & 0.635 \\
ADWG $(\mathrm{g} /$ animal/day) & $263.5 \mathrm{a}$ & $304.10 \mathrm{a}$ & 18.19 & 0.106 \\
FCR (kg DMI/ADWG) & $4.62 \mathrm{a}$ & $4.27 \mathrm{a}$ & 25.80 & 0.516 \\
\hline
\end{tabular}

$\mathrm{CV}$ - coefficient of variation; LW - live weight.

Means followed by different letters in the rows differ by the $\mathrm{F}$ test at a $5 \%$ probability level. 
Likewise, as observed in the intake in $\mathrm{kg}$ per day and in the unit of metabolic size, there was no significant impact of frame size on dry matter intake in the live weight percentage. A percentage of $3.24 \%$ of the weight of dry matter intake was found for large-framed lambs, which is similar to the $3.33 \%$ obtained for medium-framed lambs.

There was no significant difference between the frame sizes regarding their influence on the average daily weight gain. Large-framed lambs showed an average daily weight gain of $304.10 \mathrm{~g} / \mathrm{day}$, and the medium-framed lambs showed an average daily weight gain of $263.55 \mathrm{~g} /$ day. The average daily weight gain of large-framed lambs was close to the $300 \mathrm{~g} /$ day established by the NRC (1985) for lambs in this weight range fed similar protein and energy levels in their diet.

The mean value of the average daily weight gain in the present study was $283.82 \mathrm{~g}$ /day, superior to the $223.0 \mathrm{~g}$ /day obtained by Rodrigues et al. (2008) with Santa Inês lambs, with a final live weight of $30 \mathrm{~kg}$.

In their evaluation of the performance of small, medium- and large-framed lambs, Tatum et al. (1998) found greater average daily weight gain in the large-framed lambs compared with the small-framed ones. However, as demonstrated in the present study, there were no significant differences regarding average daily weight gain between the medium- and large-framed lambs.

Frame size did not affect feed conversion in Santa Inês lambs. The large-framed animals had a feed conversion ratio of 4.27, and the medium-framed lambs obtained a feed conversion ratio of 4.62 . These findings can be considered satisfactory and are explained by the energy concentration of the diet, as well as the genetic potential of the lambs, because all animals had excellent origins. In their study of Santa Inês lambs fed a similar diet, Urano et al. (2006) found average to better feed conversion obtained in the present study (3.5).

Frame size was found to have a significant effect on rump perimeter (Table 4). This result indicates that the different measures of front and back height (Table 1) led to greater rump perimeter and demonstrates that large-framed Santa Inês lambs had a greater rump perimeter, which was consistent with the findings obtained by Furusho-Garcia et al. (2000), of $63.1 \mathrm{~cm}$ for rump perimeter, with Santa Inês lambs.

The different frame sizes showed no significant differences for carcass length, rump width, chest depth, leg length or leg perimeter. Regarding the leg perimeter, this result indicates that lambs with different frame sizes showed similar morphometric carcasses in this region and are considered prime cuts of sheep carcass.
There was significant difference between the frame sizes regarding carcass conformation on Santa Inês lambs (Table 5). Large-framed lambs obtained a carcass conformation value of 3.25 , and medium-framed lambs obtained 2.83, indicating that the distribution of muscle tissue was not uniform, regardless of the frame size. However, the lambs of both frame sizes were classified as having good carcass conformation, which attests to the genetic potential of Santa Inês lambs for the production of carcasses with good conformation.

Frame size had no significant effect on kidney-pelvic fat. The value obtained for large framed lambs was 2.10 , whereas 2.66 was obtained for medium framed lambs. The frame size did not interfere with the assessment of the accumulation of visceral fat in the lambs. However, these values are slightly above the normal value of 2 , on a scale from 1 to 3 . According to Cezar \& Sousa (2006), the subcutaneous fat tissue in tropical shorn sheep is poorly developed and almost entirely deposited in the body cavities. Therefore, Burke \& Apple (2007) affirmed that shorn lambs tend to deposit large amounts of fat around theinternal organs.

Carcass fat cover had no significant difference according to the frame sizes. An average value of 3.05 was obtained for large-framed lambs, whereas 2.77 was obtained for medium-framed lambs. This suggests that large-framed lambs showed better distribution of fat in the carcass than medium-framed lambs.

Table 4 - Morphometric carcass traits in relation to frame size

\begin{tabular}{lcccc}
\hline \multirow{2}{*}{ Variable } & \multicolumn{4}{c}{ Frame size } \\
\cline { 2 - 5 } & Medium & Large & CV (\%) & P-value \\
\hline Carcass length $(\mathrm{cm})$ & 100.45 & 101.24 & 2.36 & 0.484 \\
Internal carcass length $(\mathrm{cm})$ & $65.44 \mathrm{~b}$ & $67.30 \mathrm{a}$ & 2.53 & 0.028 \\
Rump width $(\mathrm{cm})$ & 22.66 & 23.30 & 5.78 & 0.314 \\
Chest width $(\mathrm{cm})$ & 16.55 & 18.00 & 10.86 & 0.113 \\
Chest depth $(\mathrm{cm})$ & 25.66 & 26.60 & 4.58 & 0.108 \\
Rump perimeter $(\mathrm{cm})$ & $61.22 \mathrm{~b}$ & $65.00 \mathrm{a}$ & 4.16 & 0.006 \\
Leg length $(\mathrm{cm})$ & 40.44 & 41.20 & 4.01 & 0.330 \\
Leg perimeter $(\mathrm{cm})$ & 37.00 & 37.20 & 4.50 & 0.797 \\
\hline
\end{tabular}

$\mathrm{CV}$ - coefficient of variation.

Means followed by different letters in the rows differ $(\mathrm{P}<0.05)$ by the $\mathrm{F}$ test at a $5 \%$ probability level.

Table 5 - Qualitative carcass traits in relation to frame size

\begin{tabular}{lcccc}
\hline \multirow{2}{*}{ Variable } & \multicolumn{4}{c}{ Frame size } \\
\cline { 2 - 5 } & Medium & Large & CV (\%) & P-value \\
\hline Conformation & $2.83 \mathrm{~b}$ & $3.25 \mathrm{a}$ & 11.58 & 0.020 \\
Kidney-pelvic fat & 2.66 & 2.10 & 17.43 & 0.008 \\
Carcass fat cover & 2.77 & 3.05 & 11.07 & 0.084 \\
Muscle texture & 4.55 & 4.30 & 11.40 & 0.285 \\
Meat color & 2.11 & 2.10 & 22.42 & 0.959 \\
Marbling & $1.38 \mathrm{a}$ & $1.25 \mathrm{~b}$ & 34.55 & 0.515 \\
\hline
\end{tabular}

$\mathrm{CV}$ - coefficient of variation.

Means followed by different letters in the rows $\operatorname{differ}(\mathrm{P}<0.05)$ by the $\mathrm{F}$ test at a $5 \%$ probability level. 
There was no significant difference between the frame sizes in terms of texture and meat color. Large-framed lambs showed 4.30, while medium-framed animals had a value of 4.55 .

Given the results obtained for meat texture and color, it is evident that frame size does not influence those traits. According to Cezar \& Sousa (2007), the main factor that differentiates the texture and color of carcass meat is the age of the animal, which was most likely the determining factor in this research because the animals were the same age.

Marbling was influenced by frame size. The results obtained for large- and medium-framed lambs were 1.25 and 1.38 , respectively. The explanation for this result is that marbling in lamb meat is influenced mainly by genotype. It is noteworthy that this characteristic is responsible for some sensory properties, such as the flavor and tenderness of the meat.

The hot and cold carcass weights were influenced by the frame sizes of the lambs (Table 6). Large-framed lambs showed higher weight values than medium-framed lambs. Similar results were also reported by Camfield et al. (1997), who assessed the effect of frame size (medium and large) in bovines.

The frame size had no significant impact on carcass shrinkage by chilling. Large- and medium-framed lambs showed values of $1.41 \%$ and $1.77 \%$, respectively. These losses were higher compared with $1.20 \%$ found by Oliveira et al. (2002) with Santa Ines lambs finished in feedlots and slaughtered with a live weight of $43.7 \mathrm{~kg}$.

There were no significant differences in the biological, hot and cold carcass yields in relation to the frame size of the lambs, indicating that large-framed lambs showed carcass with larger edible portions compared with mediumframed lambs.

The carcass yields obtained in the present study were smaller than $56.50 \%$ and $49.79 \%$ obtained for the carcass biological and hot carcass yields, respectively, by Zundt et al. (2006) with Santa Ines lambs slaughtered with final body weight of $30.0 \mathrm{~kg}$.

The frame size had significant effect on the loin eye area of the lambs. Large- and medium-framed lambs showed loin eye areas of $13.43 \mathrm{~cm}^{2}$ and $11.40 \mathrm{~cm}^{2}$, respectively. Because the loin eye area is highly correlated with the total amount of muscle from the carcasses of lambs, according to Prado et al. (2004), this region is used as an indicator of muscle development and the amount of meat in the carcass.

The result of leg muscularity index, an indirect measure of the amount of muscle in the carcass, did not differ between the two frame sizes. Likewise, Camfield et al. (1997) did not find differences regarding carcass dressing between the different frame sizes.
Fat thickness was not affected by frame size, indicating that the frame size did not confer greater carcass protection during cooling. Currently, there is a consensus among the available studies that shorn sheep tend to have little subcutaneous fat thickness. Therefore, the values of 1.92 and $1.78 \mathrm{~mm}$ found in medium- and large-framed lambs, respectively, can be considered low considering the final live weight.

These values are consistent with those obtained by Urano et al. (2006), who studied Santa Inês lambs fed different sources of fat in the diet and slaughtered at an average live weight of $37.67 \mathrm{~kg}$, and found a fat thickness ranging from 1.30 to $1.70 \mathrm{~mm}$.

Carcass compactness was significantly different between large- and medium-framed lambs, suggesting that larger Santa Inês lambs had more compact carcasses than the smaller lambs. The average was $0.27 \mathrm{~kg} / \mathrm{cm}$ for large-framed lambs and $0.23 \mathrm{~kg} / \mathrm{cm}$ for medium-framed lambs. Similar finding was obtained by Sá et al. (2005), who reported an index of $0.25 \mathrm{~kg} / \mathrm{cm}$ for Santa Inês lambs.

The tissue composition was influenced by the frame size of the lamb. Large-framed lambs showed the following percentages: $66.36 \%$ of muscle, $22.65 \%$ of bone and $6.03 \%$ of fat (Table 7). For medium-framed lambs, the following percentages were obtained: muscle, $64.62 \%$; bone, $24.42 \%$; and fat, $5.91 \%$, indicating that frame size influence the tissue composition in the carcasses of lambs. These results were similar to the findings obtained by Araújo Filho (2008) with Santa Inês lambs finished in feedlots: $66.97 \%, 23.31 \%$ and $7.22 \%$ of muscle, bone and fat, respectively.

Frame size had no significant impact on the muscle: fat ratio. The muscle:bone ratio was 2.94 and 2.65, and the muscle:fat ratio was 11.89 and 12.87 for the large-

Table 6 - Quantitative carcass traits of lambs according to frame size

\begin{tabular}{lcccc}
\hline \multirow{2}{*}{ Variable } & \multicolumn{4}{c}{ Frame size } \\
\cline { 2 - 5 } & Medium & Large & CV (\%) & P-value \\
\hline Initial weight (kg) & $24.50 \mathrm{a}$ & $27.15 \mathrm{a}$ & 11.52 & 0.070 \\
Final weight $(\mathrm{kg})$ & $35.03 \mathrm{~b}$ & $39.50 \mathrm{a}$ & 10.39 & 0.022 \\
Hot carcass weight $(\mathrm{kg})$ & $16.28 \mathrm{~b}$ & $18.52 \mathrm{a}$ & 11.38 & 0.025 \\
Cold carcass weight $(\mathrm{kg})$ & $16.00 \mathrm{~b}$ & $18.25 \mathrm{a}$ & 11.19 & 0.020 \\
Carcass shrinkage $(\%)$ & 1.77 & 1.41 & 53.19 & 0.374 \\
Biological yield $(\%)$ & 50.62 & 50.94 & 3.33 & 0.693 \\
Hot carcass yield (\%) & 46.48 & 46.85 & 3.45 & 0.621 \\
Cold carcass yield (\%) & 45.65 & 46.18 & 3.36 & 0.464 \\
Loin eye area (cm $\left.{ }^{2}\right)$ & $11.40 \mathrm{~b}$ & $13.43 \mathrm{a}$ & 11.80 & 0.008 \\
Fat thickness (mm) & 1.92 & 1.78 & 25.44 & 0.528 \\
Leg muscularity index & 0.40 & 0.41 & 6.09 & 0.903 \\
CCI (kg/cm) & $0.24 \mathrm{~b}$ & $0.27 \mathrm{a}$ & 9.76 & 0.033 \\
\hline CV & &
\end{tabular}

$\mathrm{CV}$ - coefficient of variation; $\mathrm{CCI}$ - carcass compactness index.

Means followed by equal letters in the rows do not differ $(\mathrm{P}<0.05)$ by the $\mathrm{F}$ test at a $5 \%$ of probability level. 
and medium-framed lambs, respectively. Considering the percentage of fat and the muscle:fat ratio, the results obtained in the present study indicate that Santa Inês lambs produced lean meat. This is consistent with reports from Furusho-Garcia et al. (2006) on the high genetic potential for production of lean meat in the Santa Inês breed in Brazil.

The frame size had a significant impact on the weights of all of the commercial cuts of the lamb carcasses, and large-framed lambs had greater weights (Table 8). This was due to the greater weight of the cold carcass of these lambs. The results obtained for the weights of the commercial cuts of medium-framed lambs, with the exception of the neck weight, were similar to those obtained by Cartaxo (2006) with Santa Inês lambs slaughtered when fat.

Regarding the yields of commercial cuts, there was no significant difference. This shows that the growth rate of each region and each tissue of the body progresses until it reaches its maximum value and starts to decrease as the animal gains weight. This statement corroborates the results obtained by Huidobro \& Cañeque (1993), who examined male lambs of the Manchega breed slaughtered at different live weights $(15,25$ and $35 \mathrm{~kg})$ and found that the lightest animals $(15 \mathrm{~kg})$ had greater percentages of shoulder and

Table 7 - Tissue composition, muscle:bone and muscle:fat ratios in relation to frame size

\begin{tabular}{lcccc}
\hline \multirow{2}{*}{ Variable } & \multicolumn{4}{c}{ Frame size } \\
\cline { 2 - 5 } & Medium & Large & CV (\%) & P-value \\
\hline Muscle (\%) & $64.62 \mathrm{~b}$ & $66.36 \mathrm{a}$ & 2.18 & 0.018 \\
Bone (\%) & $24.42 \mathrm{a}$ & $22.65 \mathrm{~b}$ & 6.60 & 0.023 \\
Fat (\%) & 5.91 & 6.03 & 28.84 & 0.879 \\
Muscle:bone ratio & $2.65 \mathrm{~b}$ & $2.94 \mathrm{a}$ & 7.91 & 0.012 \\
Muscle:fat ratio & 12.87 & 11.89 & 47.22 & 0.720 \\
\hline
\end{tabular}

CV - coefficient of variation.

Means followed by different letters in the rows differ $(\mathrm{P}<0.05)$ by the $\mathrm{F}$ test at a $5 \%$ probability level.

Table 8 - Weights and yields of commercial cuts in relation to frame size

\begin{tabular}{lcccc}
\hline \multirow{2}{*}{ Variable } & \multicolumn{4}{c}{ Frame size } \\
\cline { 2 - 5 } & Medium & Large & CV (\%) & P-value \\
\hline Leg weight $(\mathrm{kg})$ & $2.45 \mathrm{~b}$ & $2.74 \mathrm{a}$ & 9.90 & 0.025 \\
Loin weight $(\mathrm{kg})$ & $1.00 \mathrm{~b}$ & $1.22 \mathrm{a}$ & 14.76 & 0.012 \\
Shoulder weight $(\mathrm{kg})$ & $1.36 \mathrm{~b}$ & $1.60 \mathrm{a}$ & 12.11 & 0.009 \\
Neck weight (kg) & 1.06 & 1.17 & 11.82 & 0.090 \\
Rib weight $(\mathrm{kg})$ & 2.21 & 2.49 & 13.38 & 0.070 \\
Leg yield $(\%)$ & 30.65 & 30.13 & 4.49 & 0.424 \\
Loin yield $(\%)$ & 12.60 & 13.34 & 6.92 & 0.091 \\
Shoulder yield $(\%)$ & 17.07 & 17.53 & 7.41 & 0.443 \\
Neck yield (\%) & 13.34 & 12.92 & 6.90 & 0.320 \\
Rib yield $(\%)$ & 27.58 & 27.23 & 4.37 & 0.536 \\
\hline
\end{tabular}

$\mathrm{CV}$ - coefficient of variation.

Means followed by different letters in the rows differ $(\mathrm{P}<0.05)$ by the $\mathrm{F}$ test at a $5 \%$ probability level. leg, whereas the heaviest animals $(35 \mathrm{~kg})$ had greater percentages of ribs. Except for the neck yield and loin yield, the other percentages were close to those reported by Urano et al. (2006) for Santa Inês slaughtered at an average live weight of $37.67 \mathrm{~kg}$.

\section{Conclusions}

Large- and medium-framed Santa Inês lambs have different performance, tissue composition and qualitative carcass traits, differing in carcass finish. Large framed Santa Inês lambs produce more compact carcasses with heavier cuts than those produced by medium-framed lambs, although with the same yield.

\section{References}

ALVES, K.S.; CARVALHO, F.F.R.; VERÁS, A.S.C. et al. Níveis de energia em dietas para ovinos Santa Inês: Desempenho. Revista Brasileira de Zootecnia, v.32, p.1937-1944, 2003.

ARAÚJO FILHO, J.T. Desempenho e características de carcaça de ovinos deslanados submetidos a diferentes dietas em confinamento. 2008. 86f. Tese (Doutorado em Zootecnia) Programa de Doutorado Integrado em Zootecnia, Universidade Federal da Paraíba, Areia.

BURKE, J.M.; APPLE, J.K. Growth performance and carcass traits of forage-fed hair sheep wethers. Small Ruminant Research, v.67, p.264-270, 2007.

CAMFIELD, P.K; BROWN, A.H.; LEWIS, P.K. et al. Effects of frame size and time-on-feed on carcass characteristics, sensory attributes, and fatty acid profiles of steers. Journal of Animal Science, v.75, p.1837-1844, 1997.

CARTAXO, F.Q. Efeitos do genótipo e da condição corporal sobre o desempenho, predição e avaliação de carcaça de cordeiros terminados em confinamento. 2006. 122f. Dissertação (Mestrado em Zootecnia) - Universidade Federal da Paraíba, Areia.

CEZAR, M.F.; SOUSA, W.H. Avaliação e utilização da condição corporal como ferramenta de melhoria da reprodução e produção de ovinos e caprinos de corte. Revista Brasileira de Zootecnia, v.35, p.541-565, 2006 (supl. especial).

CEZAR, M.F.; SOUSA, W.H. Carcaças ovinas e caprinas: obtençãoavaliação-classificação. Uberaba: Editora Agropecuária Tropical, 2007. 232p.

COLOMER-ROCHER, F.; MORAND-FEHR, P.; KIRTON, A.H. et al. Metodos normalizados para el studio de los caracteres cuantitativos y cualitativos de las canales caprinas y ovinas. Madrid-España, 1988. 41p.(Cadernos INIA, 17)

FURUSHO-GARCIA, I.F.F.; PEREZ, J.R.O.; OLIVEIRA, M.V. Características de carcaça de cordeiros Texel x Bergamácia, Texel $\mathrm{x}$ Santa Inês e Santa Inês puros, terminados em confinamento, com casa de café como parte da dieta. Revista Brasileira de Zootecnia, v.29, p.253-260, 2000.

FURUSHO-GARCIA, I.F.; PEREZ, J.R.O.; SARITA BONAGURIO, S et al. Estudo alométrico dos cortes de cordeiros santa inês puros e cruzas. Revista Brasileira de Zootecnia, v.35, p.1416-1422, 2006.

HUIDOBRO, F.R.; CAÑEQUE, V. Producción de carne en corderos de raza Manchega. ii. confromación y estado de engrasamiento de la canal y proporción de piezas en distintos tipos comerciales. Investigación Agraria - Produccíon y Sanidad Animal, v.8, p.233-243, 1993.

NATIONAL RESEARCH COUNCIL - NRC. Nutrient requirements of sheep. 6.ed. Washington, D.C.: National Academy Press, 1985. 99p. 
NEIVA, J.N.M.; TEIXEIRA, M.; TURCO, S.H.N. et al. Efeito climático sobre parâmetros produtivos e fisiológicos de ovinos Santa Inês mantidos em confinamento na região litorânea do nordeste do Brasil. Revista Brasileira de Zootecnia, v.33, p.668-678, 2004.

OLIVEIRA, M.V.M.; PÉREZ, J.R.O.; ALVES, E.L. et al. Rendimento de carcaça, mensurações e peso de cortes comerciais de cordeiros Santa Inês e Bergamácia alimentados com dejetos de suínos em confinamento. Revista Brasileira de Zootecnia, v.31, n.3, p.1451-1458, 2002 (supl.).

ORTIZ, J.S.; COSTA, C.; GARCIA, C.A. et al. Medidas objetivas das carcaças e composição química do lombo de cordeiros alimentados e terminados com três níveis de proteína. Revista Brasileira de Zootecnia, v.34, p.2382-2389, 2005.

OSÓRIO, J.C.S.; OSÓRIO, M.T.M. Produção de carne ovina: Técnicas de avaliação "in vivo" e na carcaça. Pelotas: UFPel, 2003. 73p.

PRADO, C.S.; PÁDUA, J.T.; CORREA, M.P.C. et al. Comparação de diferentes métodos de avaliação da área de olho de lombo e cobertura de gordura em bovinos de corte. Ciência Animal Brasileira, v.5, p.141-149, 2004.

PURCHAS, R.W.; DAVIES, A.S.; ABDUKKAH, A.Y. An objective measure of muscularity: changes with animal growth and differences between genetic lives of southdown sheep. Meat Science, v.30, p.81-94, 1991.

REIS, W.; JOBIM, C.C.; MACEDO, F.A.F. et al. Características da carcaças de cordeiros alimentados com dietas contendo grãos de milho conservados em diferentes formas. Revista Brasileira de Zootecnia, v.30, p.1308-1315, 2001.

RODRIGUES, G.H.; SUSIN, I.; PIRES, A.V. et al. Substituição do milho por polpa cítrica em rações com alta proporção de concentrado para cordeiros confinados. Ciência Rural, v.38, p.789-794, 2008.

SÁ, J.L.; SIQUEIRA, E.R.; SÁ, C.O. et al. Características de carcaça de cordeiros Hampshire Down e Santa Inês sob diferentes fotoperíodos. Pesquisa Agropecuária Brasileira, v.40, p.289-297, 2005.

TATUM, J.D.; DEWALT, M.S.; LEVALLEY, S.B. et al. Relations of feeder lamb frame size to feedlot gain and cacass yield and quality grades. Journal of Animal Science, n.76, p.435-440, 1998.

TATUM, J.D.; DOLEZAL, H.G.; WILLIAMS JR., F.L. et al. Effects of feeder-cattle frame size and muscle thickness growth and carcass growth and carcass development. II. Absolute growth and associated changes in carcass composition. Journal of Animal Science, n.62, p.121-131, 1986.

URANO, F.S.; PIRES, A.V.; SUSIN, I. et al. Desempenho e características da carcaça de cordeiros confinados alimentados com grãos de soja. Pesquisa Agropecuária Brasileira, v.41, p.1525-1530, 2006.

ZUNDT, M.; MACEDO, F.A.F.; ASTOLPHI, J.L.L. et al. Desempenho e características de carcaça de cordeiros Santa Inês confinados, filhos de ovelhas submetidas à suplementação alimentar durante a gestação. Revista Brasileira de Zootecnia, v.35, p.928-935, 2006. 